\title{
Infrared temperature measurement and increasing infrared measurement accuracy in the context of machining process
}

\author{
Masoudi, S. ${ }^{a}{ }^{,}$, Gholami, M.A. ${ }^{b}$, Janghorban lariche, M. ${ }^{c}$, Vafadar, A. ${ }^{d}$ \\ ${ }^{a}$ Young Researchers and Elite Club, Najafabad Branch, Islamic Azad University, Najafabad, Iran \\ ${ }^{b}$ Department of Mechanical Engineering, Shiraz Branch, Islamic Azad University, Shiraz, Iran \\ ${ }^{\mathrm{C}}$ Abadan School of Medical Sciences, Abadan, Iran \\ ${ }^{\mathrm{d}}$ School of Engineering, Edith Cowan University, Perth, Australia
}

\begin{abstract}
A B S T R A C T
One of the major challenges in the machining process is measuring the temperature accurately which has a considerable importance in calibrating finite element models and investigating thermodynamic of machining process. In the present paper, one of the effective methods for measuring temperature in the machining processes - i.e. infrared imaging - is used and effective parameters which increase measurement accuracy are investigated. One of the most effective parameter in the temperature measurement accuracy of infrared imaging is extracting and calibrating the emissivity coefficient for different temperature ranges. The obtained results show that the lack of precision calibration of the emissivity for different temperature ranges may cause high error in the measurement results. To measure temperature, several experiments are performed for turning a thin walled workpiece which is made of aluminium alloy Al-7075 and the effects of the machining parameters and tool material - polycrystalline diamond (PCD) and cemented carbide - are studied. Based on the achieved results, it can be concluded that the generated temperature in the cutting area can be decreased significantly by using PCD tools and selecting appropriate machining parameters.
\end{abstract}

\section{ARTICLE INFO}

Keywords:

Machining

IR temperature measurement

Emissivity

PCD tool

Carbide tool

Al-7075

*Corresponding author: smasoudi86@gmail.com (Masoudi, S.)

Article history:

Received 25 June 2017

Revised 14 October 2017

Accepted 20 October 2017

\section{References}

[1] Wang, Z., Basu, S., Saldana, C. (2017). Low-temperature machining in a fully submerged cryogenic environment, Machining Science and Technology, Vol. 21, No. 1, 19-36, doi: 10.1080/10910344.2016.1260428.

[2] Masoudi, S., Amirian, G., Saeedi, E., Ahmadi, M. (2015). The effect of quench-induced residual stresses on the distortion of machined thin-walled parts, Journal of Materials Engineering and Performance, Vol. 24, No. 10, 3933-3941, doi: 10.1007/s11665-015-1695-7.

[3] Riou, O., Guiheneuf, V., Delaleux, F., Logerais, P.-O., Durastanti, J.-F. (2016). Accurate methods for single-band apparent emissivity measurement of opaque materials, Measurement, Vol. 89, 239-251, doi: 10.1016/ j.measurement.2016.04.006.

[4] Thepsonthi, T., Özel, T. (2015). 3-D finite element process simulation of micro-end milling Ti-6Al-4V titanium alloy: Experimental validations on chip flow and tool wear. Journal of Materials Processing Technology, Vol. 221, 128-145, doi: 10.1016/i.jmatprotec.2015.02.019.

[5] Heigel, J.C., Whitenton, E., Lane, B., Donmez, M.A., Madhavan, V., Moscoso-Kingsley, W. (2017). Infrared measurement of the temperature at the tool-chip interface while machining Ti-6Al-4V, Journal of Materials Processing Technology, Vol. 243, 123-130, doi: 10.1016/j.jmatprotec.2016.11.026.

[6] Jiang, F., Liu, Z., Wan, Y., Shi, Z., Zhang, H. (2016). Experimental investigation of cutting tool temperature during slot milling of AerMet 100 steel, Proceedings of the Institution of Mechanical Engineers, Part B: Journal of Engineering Manufacture, Vol. 230, No. 5, 838-847, doi: 10.1177/0954405414563421. 
[7] Tabei, A., Shih, D.S., Garmestani, H., Liang, S.Y. (2016). Micro-texture evolution in aggressive machining of al alloy 7075, Materials and Manufacturing Processes, Vol. 31, No. 13, 1709-1717, doi: 10.1080/10426914.2015. 1090597.

[8] Amini, S., Khosrojerdi, M.R., Nosouhi, R., Behbahani, S. (2014). An experimental investigation on the machinabiity of $\mathrm{Al}_{2} \mathrm{O}_{3}$ in vibration-assisted turning using PCD tool, Materials and Manufacturing Processes, Vol. 29, No. 3, 331336, doi: $10.1080 / 10426914.2013 .864411$.

[9] Davoodi, B., Hosseinzadeh, H. (2012). A new method for heat measurement during high speed machining, Measurement, Vol. 45, No. 8, 2135-2140, doi: 10.1016/j.measurement.2012.05.020.

[10] Yashiro, T., Ogawa, T., Sasahara, H. (2013). Temperature measurement of cutting tool and machined surface layer in milling of CFRP, International Journal of Machine Tools and Manufacture, Vol. 70, 63-69, doi: 10.1016/j.ijmachtools.2013.03.009.

[11] Svetlitza, A., Slavenko, M., Blank, T., Brouk, I., Stolyarova, S., Nemirovsky, Y. (2014). THz measurements and calibration based on a blackbody source. IEEE Transactions on Terahertz Science and Technology, Vol. 4, No. 3, 347359, doi: 10.1109/TTHZ.2014.2309003.

[12] Quan, Y., Xu, H., Ke, Z. (2011). Research on some influence factors in high temperature measurement of metal with thermal infrared imager, Physics Procedia, Vol. 19, 207-213, doi: 10.1016/i.phpro.2011.06.150.

[13] Liu, D., Wang, G., Nie, Z., Rong, Y.K. (2016). An in-situ infrared temperature-measurement method with back focusing on surface for creep-feed grinding, Measurement, Vol. 94, 645-652, doi: 10.1016/i.measurement. 2016.09.013.

[14] Müller, B., Renz, U. (2003). Time resolved temperature measurements in manufacturing, Measurement, Vol. 34, No. 4, 363-370, doi: 10.1016/j.measurement.2003.08.009.

[15] Hou, J., Zhao, N., Zhu, S. (2011). Influence of cutting speed on flank temperature during face milling of magnesium alloy, Materials and Manufacturing Processes, Vol. 26, No. 8, 1059-1063, doi: 10.1080/10426914.2010. $\underline{536927 .}$

[16] Hamlaoui, N., Azzouz, S., Chaoui, K., Azari, Z., Yallese, M.-A. (2017). Machining of tough polyethylene pipe material: Surface roughness and cutting temperature optimization, The International Journal of Advanced Manufacturing Technology, Vol. 92, No. 5-8, 2231-2245, doi: 10.1007/s00170-017-0275-4.

[17] Cuesta, M., Aristimuño, P., Garay, A., Arrazola, P.J. (2016). Heat transferred to the workpiece based on temperature measurements by IR technique in dry and lubricated drilling of Inconel 718, Applied Thermal Engineering, Vol. 104, 309-318, doi: 10.1016/j.applthermaleng.2016.05.040.

[18] Vitkovskii, V.V., Gorshenev, V.G., Potapov, Y.F. (2009). Measurement of spectral directional emissivity of materials and coatings in the infrared region of spectrum, Thermal engineering, Vol. 56, No. 3, 245-248, doi: 10.1134/ $\underline{\mathrm{S} 0040601509030100 .}$.

[19] Armendia, M., Garay, A., Villar, A., Davies, M.A., Arrazola, P.J. (2010). High bandwidth temperature measurement in interrupted cutting of difficult to machine materials, CIRP Annals, Manufacturing Technology, Vol. 59, No. 1, 97-100, doi: 10.1016/j.cirp.2010.03.059.

[20] Meca Meca, F.J., Rodríguez Sanchez, F.J., Sanchez, P.M. (2002). Calculation and optimisation of the maximum uncertainty in infrared temperature measurements taken in conditions of high uncertainty in the emissivity and environment radiation values, Infrared Physics \& Technology, Vol. 43, No. 6, 367-375, doi: 10.1016/S13504495(02)00125-1.

[21] Boué, C., Holé, S. (2012). Infrared thermography protocol for simple measurements of thermal diffusivity and conductivity, Infrared Physics \& Technology, Vol. 55, No. 4, 376-379, doi: 10.1016/j.infrared.2012.02.002.

[22] Valiorgue, F., Brosse, A., Naisson, P., Rech, J., Hamdi, H., Bergheau, J. M. (2013). Emissivity calibration for temperatures measurement using thermography in the context of machining, Applied Thermal Engineering, Vol. 58, No. 1-2, 321-326, doi: 10.1016/i.applthermaleng.2013.03.051.

[23] Li, G., Rahim, M.Z., Ding, S., Sun, S. (2016). Performance and wear analysis of polycrystalline diamond (PCD) tools manufactured with different methods in turning titanium alloy Ti-6Al-4V, The International Journal of Advanced Manufacturing Technology, Vol. 85, No. 1-4, 825-841, doi: 10.1007/s00170-015-7949-6.

[24] Wen, C.-D., Mudawar, I. (2006). Modeling the effects of surface roughness on the emissivity of aluminum alloys, International Journal of Heat and Mass Transfer, Vol. 49, No. 23-24, 4279-4289, doi: 10.1016/ j.ijheatmasstransfer.2006.04.037. 


\title{
Infrardeče merjenje temperature in povečanje natančnosti infrardečega merjenja v kontekstu obdelovalnega postopka
}

\author{
Masoudi, S. ${ }^{a}{ }^{,}$, Gholami, M.A. ${ }^{b}$, Janghorban lariche, M. ${ }^{c}$, Vafadar, A. ${ }^{d}$ \\ ${ }^{a}$ Young Researchers and Elite Club, Najafabad Branch, Islamic Azad University, Najafabad, Iran \\ ${ }^{b}$ Department of Mechanical Engineering, Shiraz Branch, Islamic Azad University, Shiraz, Iran \\ 'Abadan School of Medical Sciences, Abadan, Iran \\ ${ }^{\mathrm{d}}$ School of Engineering, Edith Cowan University, Perth, Australia
}

\section{POVZETEK}

Pri obdelovalnih postopkih je eden glavnih izzivov natančno merjenje temperature. To ima velik pomen pri umerjanju modelov končnih elementov in proučevanju termodinamike obdelovalnega procesa. $\mathrm{V}$ prispevku je uporabljena ena izmed učinkovitih metod za merjenje temperature pri obdelovalnih postopkih, infrardeče snemanje, preučeni pa so parametri, ki učinkovito povečujejo natančnost merjenja. Eden izmed najučinkovitejših parametrov pri merjenju temperaturne $\mathrm{z}$ ustvarjanjem infrardeče slike je ekstrakcija in umerjanje emisijskega koeficienta za različne temperature. Dobljeni rezultati kažejo, da lahko pomanjkanje natančnega umerjanja emisije za različna temperaturna področja povzroči veliko napako pri rezultatih merjenja. Merjenje temperature je izvedeno v več poskusih struženja tankostenskega obdelovanca iz aluminijeve zlitine Al-7075. Proučeni so učinki obdelovalnih parametrov in orodnega materiala - polikristalnega diamanta (PCD) in karbidne trdnine. $\mathrm{Na}$ podlagi dobljenih rezultatov sklepamo, da se z uporabo PCD orodij in primerno izbranimi obdelovalnimi parametri močno zniža temperatura v območju rezanja.

\section{PODATKI O ČLANKU}

Ključne besede:

Obdelava

IR meritve temperature

Emisije

Orodja iz PCD

Orodja iz karbidne trdnine

Al-7075

*Kontaktna oseba: smasoudi86@gmail.com (Masoudi, S.)

Zgodovina članka:

Prejet 25. junija 2017

Popravljen 14. oktobra 2017

Sprejet 20. oktobra 2017 